\title{
Towards a Starter Culture for Cocoa Fermentation by the Selection of Acetic Acid Bacteria
}

\author{
Lucie Farrera ${ }^{1,2, *}$, Alexandre Colas de la Noue ${ }^{2}$, Caroline Strub ${ }^{2}$, Benjamin Guibert ${ }^{1}$, Christelle Kouame ${ }^{1} \mathbb{( D}$, \\ Joël Grabulos ${ }^{1}$, Didier Montet ${ }^{1}$ and Corinne Teyssier ${ }^{2}$ \\ 1 UMR 95 QualiSud, Centre de Coopération Internationale en Recherche Agronomique pour le \\ Développement (CIRAD), Université de Montpellier, Avignon Université, Institut Agro, IRD, Université de \\ La Réunion, 34398 Montpellier CEDEX 5, France; benjamin.guibert@cirad.fr (B.G.); \\ christellekouame@yahoo.fr (C.K.); joel.grabulos@cirad.fr (J.G.); didier.montet@cirad.fr (D.M.) \\ 2 Qualisud, Université de Montpellier, Avignon Université, CIRAD, Institut Agro, IRD, Université de La \\ Ré-union, 34398 Montpellier CEDEX 5, France; Alexandre.colas-de-la-noue@umontpellier.fr (A.C.d.1.N.); \\ caroline.strub@umontpellier.fr (C.S.); corinne.teyssier@umontpellier.fr (C.T.) \\ * Correspondence: lucie.farrera@gmail.com
}

Citation: Farrera, L.; Colas de la Noue, A.; Strub, C.; Guibert, B.;

Kouame, C.; Grabulos, J.; Montet, D.; Teyssier, C. Towards a Starter Culture for Cocoa Fermentation by the Selection of Acetic Acid Bacteria. Fermentation 2021, 7, 42. https:// doi.org/10.3390/fermentation7010042

Academic Editor: Luca Settanni

Received: 24 February 2021

Accepted: 15 March 2021

Published: 20 March 2021

Publisher's Note: MDPI stays neutral with regard to jurisdictional claims in published maps and institutional affiliations.

Copyright: (c) 2021 by the authors Licensee MDPI, Basel, Switzerland. This article is an open access article distributed under the terms and conditions of the Creative Commons Attribution (CC BY) license (https:// creativecommons.org/licenses/by/ $4.0 /)$.

\begin{abstract}
Acetic acid bacteria are involved in many food and beverage fermentation processes. They play an important role in cocoa bean fermentation through their acetic acid production. They initiate the development of some of the flavor precursors that are necessary for the organoleptic quality of cocoa, and for the beans' color. The development of starter cultures with local strains would enable the preservation of the microbial biodiversity of each country in cocoa-producing areas, and would also control the fermentation. This approach could avoid the standardization of cocoa bean fermentation in the producing countries. One hundred and thirty acetic acid bacteria were isolated from three different cocoa-producing countries, and were identified based on their 16S rRNA gene sequence. The predominate strains were grown in a cocoa pulp simulation medium (CPSM$\mathrm{AAB}$ ) in order to compare their physiological traits regarding their specific growth rate, ethanol and lactic acid consumption, acetic acid production, and relative preferences of carbon sources. Finally, the intraspecific diversity of the strains was then assessed through the analysis of their genomic polymorphism by (GTG) $)_{5}$-PCR fingerprinting. Our results showed that Acetobacter pasteurianus was the most recovered species in all of the origins, with 86 isolates out of 130 cultures. A great similarity was observed between the strains according to their physiological characterization and genomic polymorphisms. However, the multi-parametric clustering results in the different groups highlighted some differences in their basic metabolism, such as their efficiency in converting carbon substrates to acetate, and their relative affinity to lactic acid and ethanol. The A. pasteurianus strains showed different behaviors regarding their ability to oxidize ethanol and lactic acid into acetic acid, and in their relative preference for each substrate. The impact of these behaviors on the cocoa quality should be investigated, and should be considered as a criterion for the selection of acetic acid bacteria starters.
\end{abstract}

Keywords: cocoa bean fermentation; acetic acid bacteria; lactic acid; acetic acid; ethanol; $(\mathrm{GTG})_{5}$ rep PCR

\section{Introduction}

Cocoa beans are collected from the fruits, called 'pods', of the cocoa tree Theobroma cacao L., which are transformed by a succession of post-harvest treatments, e.g., opening, fermentation, and drying [1]. Nowadays, cocoa is produced in 50 tropical countries in a well-defined area called the 'cocoa belt'. The main producing countries are Ivory Coast, Ghana, Nigeria, and Cameroon in Africa; Inperformedsia and Malaysia in Asia; and Brazil, Ecuador, Mexico, and Peru in Latin America [2]. The traditional fermentation of cocoa allows the development 
of its organoleptic properties, but also because it helps in controlling negative microflora that could affect the final product's safety and quality, such as mycotoxinogenic moulds.

The spontaneous fermentation of cocoa beans lasts between 4 to 7 days based on the succession of microorganisms, which are mainly yeasts, lactic acid bacteria (LAB), and acetic acid bacteria (AAB) [3-11]. The fermentation process takes place in the mucilaginous pulp surrounding the beans, which forms a barrier to the air. The pulp is white, viscous, and has a low $\mathrm{pH}$, ranging between 3 and 4 . It is mainly composed of $80-90 \%$ water, $10-15 \%$ sugar (glucose, fructose, and sucrose), 2-3\% pentosans, $2 \%$ citric acid, and 1\% pectin. Its composition varies all along the fermentation process as a consequence of microbial activities [4,12].

Yeasts and LAB perform the anaerobic fermentation. Yeasts metabolize glucose, fructose, and citric acid to produce ethanol and carbon dioxide [3-6,13-17]. Meanwhile, LAB consume the glucose, fructose and citric acid to generate lactic acid, acetic acid, ethanol, and mannitol. The hydrolysis of pectin by yeasts progressively reduces the viscosity of the pulp and allows air to penetrate the bean mass [18]. This air intake is allowed by pulp liquefaction, combined with lactic acid and ethanol, and it progressively leads to favorable conditions for the growth of Acetic Acid Bacteria (AAB). Bean turning is also often performed in order to oxygenate the pulp mass and promote aerobic microorganisms $[1,6,16]$. In this environment, AAB quickly metabolizes ethanol to produce acetic acid, but it also produces lactic acid, which is considered to be an undesirable fermentation by-product which can lead to off flavors $[7,10,19]$. Acetification plays a key role in cocoa fermentation because acetic acid penetrates the cotyledons and destabilizes the subcellular structure, with an impact on the proteins, polyphenols, and lipids. It promotes the production of flavor precursors, and notably amino-acids liberation through proteolysis, which will further interact with sugars and polyphenols during the roasting process [20]. The color of the beans is also affected through the degradation of polyphenols, particularly anthocyanins, enhanced by acetic acid [21,22]. Acetic acid also prevents seed germination by participating in the death of the embryo, coupled with the temperature increase due to $A A^{\prime}$ 's exothermic metabolism. Finally, the acetic acid is mostly eliminated by sun drying [23].

In cocoa, the group/genus of Acetobacter is predominant. Acetobacter is a genus of acetic acid bacteria (AAB) which belong to the family of Acetobacteraceae in the Alphaproteobacteria class $[24,25]$. Acetobacter species are involved in many food and beverage fermentations with sugar and alcohol rich environments [26]. The interspecific diversity of $\mathrm{AAB}$ involved in cocoa fermentation has been well documented using culture-dependent and -independent methods. Most of the studies revealed that Acetobacter is the most prevalent genus, followed by two other genera, Gluconobacter and Gluconacetobacter [7,10]. The major species found are Acetobacter pasteurianus, Acetobacter tropicalis, Acetobacter senegalensis, and Acetobacter syzygii $[9,17,18,21,27-29]$. Other species have been reported in different countries, such as Acetobacter malorum and Acetobacter fabarum in Brazil [17,30], and Acetobacter lovaniensis in Ghana and Ivory Coast [10,31]. However, A. pasteurianus dominates fermentations among all of the producing countries $[9,10,16,17,19,20,27,31]$. Although A. pasteurianus has been frequently isolated, and appears to have a key role in the fermentation process, to date, no study has reported a potential intraspecific diversity according to the country of origin.

Some studies have reported the interspecific diversity of AAB using the (GTG) $)_{5}$ fingerprinting molecular method based on the analysis of genomic polymorphisms, they are repeated sequences found in the bacterial in the bacterial genome. [10,32]. This method allowed the identification of isolates at the species level, and could be used for intraspecific diversity analysis. Among AAB species, most A. pasteurianus strains showed physiological traits that were particularly well suited to the harsh conditions found in cocoa fermentation [33]. This species is highly tolerant to temperature, ethanol, and acetic acid in low $\mathrm{pH}$ environments [34,35]. Lefeber et al. [36] studied the metabolism of three A. pasteurianus strains which were representative of different sub clusters discriminated by (GTG) ${ }_{5}$-PCR 
banding patterns in a previous study [10]. They compared their growth kinetics, substrate consumption, and metabolite production, and highlighted substantial differences regarding their metabolism. However, this study only focused on strains isolated in the same country.

In cocoa fermentation, Acetobacter-and more specifically A. pasteurianus-strains use lactic acid and ethanol $[9,10]$, and display a separate metabolism during the co-consumption of these two substrates. While ethanol oxidation leads mostly to acetic acid production, lactic acid is mainly degraded through the tricarboxylic acid (TCA) cycle via pyruvate, and it provides a carbon source for biomass precursors, notably for amino acid synthesis. A substantial part of the lactic acid is also oxidized to acetoin, and a smaller part to acetic acid production [37]. These metabolites are crucial for the flavor of the chocolate, but can also diminish the growth of ochratoxinogenic fungi when fermentations are going well [38]. Starters composed of strains from the microbial consortium of cocoa (yeasts, $\mathrm{LAB}$, and $\mathrm{AAB}$ ) have been developed to control and improve cocoa fermentation [36,38-41]. The inoculation of a microbial cocktail isolated from Ghana, composed of Saccharomyces cerevisiae H5S5K23, Lactobacillus fermentum 222, and A. pasteurianus 386B, enhanced the cocoa bean fermentation process and improved the final chocolate quality [13]. A similar result was obtained in Brazil by the inoculation of S. cerevisiae UFLA CCMA 200, Lactobacillus plantarum CCMA 0238 and A. pasteurianus CCMA 0241 strains [40]. The analysis of the intraspecific diversity of the strains isolated from different countries could be of interest for the development of indigenous starters. It would allow the maintenance of the biodiversity of each producing country by avoiding the use of microorganisms from foreign countries. Moreover, it might help to avoid the standardization of cocoa bean fermentation all around the globe.

The aim of our study was to analyze the intraspecific diversity of the most prevalent $A$. pasteurianus strains isolated from cocoa fermentation in three different countries. The behavior of $A$. pasteurianus strains was studied by analyzing the target metabolites in a medium that simulates cocoa pulp, considering their specific growth rate, ethanol and lactic acid consumption, and acetic acid production, along with a genomic polymorphism analysis performed by $(\mathrm{GTG})_{5}$ rep-PCR fingerprinting.

\section{Material and Methods}

\subsection{Cocoa Bean Sampling}

Cocoa bean fermentation samplings were performed in three different countries: Mexico (MX), Ivory Coast (CI), and French Guiana (GF) (Table 1). The samplings were performed whilst making sure to respect the local practices from each producing country. The AAB strains were isolated all along the fermentation process, with the aim to collect a wide range of $\mathrm{AAB}$ diversity. In Mexico, two cocoa bean samplings were realized during the main crop (February 2018) and during the mid-crop (October 2018), respectively, in Comalcalco and Tabasco. For the main crop, the sampling was realized at 2, 4, and 5 days of fermentation, and for the mid-crop, all of the fermentation days were sampled from days 0 to 4 . Two campaigns of sampling were performed in Ivory Coast: the first in 2016 in Wagana (Fermentation Center of the company Cemoi) where sampling was performed daily from days 0 to 6 . The second sampling was performed in Abidjan in 2018, where cocoa beans were sampled daily from days 0 to 7 . In addition, one cocoa bean fermentation realized in French Guiana was sampled daily from days 0 to 7 .

Table 1. Data concerning the cocoa bean sampling.

\begin{tabular}{cccccc}
\hline Origin & $\begin{array}{c}\text { Sampling } \\
\text { Date }\end{array}$ & $\begin{array}{c}\text { Geographical } \\
\text { Area }\end{array}$ & $\begin{array}{c}\text { Fermentation } \\
\text { Type }\end{array}$ & $\begin{array}{c}\text { Duration of } \\
\text { Fermentation } \\
\text { (Days) }\end{array}$ & $\begin{array}{c}\text { Number of } \\
\text { Fermentation } \\
\text { Box/Heap }\end{array}$ \\
\hline Ivory Coast & 2016 & Wagana & Box & 6 & 6 \\
Ivory Coast & 2018 & Abidjan & Heap & 7 & 1 \\
French Guiana & 2017 & Combi & Box & 7 & 1 \\
Mexico & $02 / 2018$ & Comalcalco & Box & 5 & 2 \\
Mexico & $10 / 2018$ & Comalcalco & Box & 4 & 2 \\
\hline
\end{tabular}




\subsection{Acetic Acid Bacteria Strains Isolation}

Samples were withdrawn from the fermenting cocoa bean mass for microbiological analysis. The specific medium for AAB (Kneifel medium) was used [41], containing $20 \mathrm{~mL} / \mathrm{L}$ ethanol, an antifungal agent (Cycloheximide) at $100 \mathrm{mg} / \mathrm{L}$ (Sigma-Aldrich, Saint-Louis, MO, USA), and an antibiotic (Penicillin G) at $12.5 \mathrm{mg} / \mathrm{L}$ (Sigma-Aldrich), which prevents the growth of yeast and LAB. This medium also contained the $\mathrm{pH}$ indicator Bromocresol green (Sigma-Aldrich), which turned from blue to yellow/green when the medium acidified. Acetobacter pasteurianus LMG $01262^{\mathrm{T}}$ was used as the reference strain. It was purchased from the BCCM/LMG (Belgian Co-ordinated Collections of Microorganisms) Bacteria collection (Ghent, Belgium). The recommendations of the BCCM/LMG were followed for its culture and conservation (http://bccm.belspo.be/, accessed on 24 February 2021). The strains were cultured in CPSM-AAB; a specific liquid medium developed by Moens et al. [42] called 'Cocoa Pulp Simulation Medium for AAB' (CPSM$A A B)$. It reproduced the conditions found after the two days of fermentation necessary for the development of AAB. It is composed of $1 \%$ ethanol (Honeywell); $10 \mathrm{~g} / \mathrm{L}$ lactic acid (Sigma-Aldrich); $10 \mathrm{~g} / \mathrm{L}$ yeast extract (Becton Dickinson), $5 \mathrm{~g} / \mathrm{L}$ soya peptone (Merck GaA), and $1 \mathrm{~mL} / \mathrm{L}$ Tween 80 (PanReac) at $\mathrm{pH} 4.5$. All of the strains were kept frozen at $-80^{\circ} \mathrm{C}$ in CPSM-AAB supplemented with 33\% $(v / v)$ glycerol.

\subsection{Bacterial Species Identification}

A Gram stain was performed on the colonies with a yellow/green halo on the Kneifel medium. Then Gram-negative ellipsoidal bacilli were identified by $16 \mathrm{~S}$ rRNA gene sequencing. A rapid DNA extraction was performed as described previously [43]. Then, the $16 \mathrm{~S}$ rRNA gene was amplified by PCR using the primer pair 27F (5'-GTGCTGCAGAGAGTTTG ATCCTGGCTCAG-3') and 1492R (5'-CACGGATCCTACGGGTACCTTGTTACGACTT-3'). The size of the expected amplicon was about $1500 \mathrm{bp}$. The PCR was performed in a $50 \mu \mathrm{L}$ reaction volume containing GoTaq ${ }^{\circledR}$ reaction buffer $(1 \times), 2 \mu \mathrm{M}$ of each dNTP, $0.2 \mu \mathrm{M}$ of each primer, 1.25 unity per reaction of GoTaq ${ }^{\circledR}$ G2 DNA polymerase (Promega), and 5-40 ng of DNA. Amplification was carried out under the following conditions: an initial denaturation step at $94{ }^{\circ} \mathrm{C}$ for $3 \mathrm{~min}$ followed by 35 cycles of at $94{ }^{\circ} \mathrm{C}$ for $30 \mathrm{~s}, 55^{\circ} \mathrm{C}$ for $30 \mathrm{~s}, 72{ }^{\circ} \mathrm{C}$ for $30 \mathrm{~s}$ and a final elongation step at $72{ }^{\circ} \mathrm{C}$ for $5 \mathrm{~min}$ [44]. The control of the amplification was performed on $0.8 \%$ agarose gels in $1 \times$ TAE (Tris acetate-EDTA, Euromedex, Souffelweyersheim, France) at $100 \mathrm{~V}$ for $30 \mathrm{~min}$. Then, the PCR products were sequenced according to the Sanger method (Genseq, Montpellier, France). The sense or antisense strand DNA sequences were analyzed and corrected with Bioedit Sequence Alignment Editor (v. 7.0.5.3, Applied Biosystems, Carlsbad, CA, USA). The software Geneious (v. 2019.0.4, Invitrogen Corporation, Auckland, New Zeland) allowed us to obtain a complete sequence. The sequence was compared with Genbank using the Blastn algorithm [45] on the NCBI website (https:/ / blast.ncbi.nlm.nih.gov / Blast.cgi, accessed on 24 February 2021).

The 16S rRNA gene sequences of AAB species (type strains), mostly of the genus Acetobacter, identified from the NCBI database were used to compare the analysis of the sequences of the 16S rRNA genes. The pairwise similarity was calculated with the MEGAX software (v. 10.1.7), by alignment with MUSCLE. A phylogenetic tree was also constructed with the Megax software (v. 10.1.7) using the neighbor-joining [46] and maximum-parsimony [47] methods. The statistical robustness of the topology of the tree was evaluated by bootstrap analysis (1000 repetitions) [47].

\subsection{Biochemical Characterization of Acetobacter pasteurianus}

\subsubsection{Determination of the Growth Kinetics}

The strains were transferred from $-80{ }^{\circ} \mathrm{C}$ stock cultures to the Kneifel agar medium, and were incubated aerobically at $30^{\circ} \mathrm{C}$ for $48 \mathrm{~h}$. Subsequently, a colony was picked form the agar medium and inoculated in liquid CPSM-AAB in order to obtain pre-cultures. The strains were cultivated overnight at $32{ }^{\circ} \mathrm{C}$. After the overnight cultivation, the absorbance was measured at $600 \mathrm{~nm}$, and the cultures were prepared in sterile 96-well plates 
with a final volume of $200 \mu \mathrm{L}$ and an initial optical density (OD) of 0.01 . Their growth kinetics were monitored by absorbance measurement at $600 \mathrm{~nm}$ with a microplate reader (TECAN $^{\circledR}$, Lyon, France). The plates were stirred at $150 \mathrm{rpm}$ for $600 \mathrm{~s}$ and, and the OD at $600 \mathrm{~nm}\left(\mathrm{OD}_{600}\right)$ was monitoring automatically every $10 \mathrm{~min} 30 \mathrm{~s}$ for $20 \mathrm{~h}$. The maximal specific growth rate was calculated by extracting the slope of $\ln \left(\mathrm{OD}_{600}\right)=\mathrm{f}(\mathrm{time})$ and taking the maximal value.

\subsubsection{Quantification of the Metabolite Consumption and Production}

The pre-cultures at $32{ }^{\circ} \mathrm{C}$ in CPSM for AAB $(\mathrm{pH} 4.5)$ were prepared as described for the measurement of the specific growth rate. The $\mathrm{OD}_{600} \mathrm{~nm}$ was measured, and the cultures were prepared in sterile $50 \mathrm{~mL}$ containers with $5 \mathrm{~mL}$ of CPSM-AAB (pH 4.5) at $32{ }^{\circ} \mathrm{C}$, without agitation, at an initial OD of 0.02. The sampling was performed at $18 \mathrm{~h}$ and $40 \mathrm{~h}$, and only samples with an $\mathrm{OD}_{600}<3$ were selected, because the main substrate- ethanolwas not exhausted, in order to determine the relative consumption of lactic acid, mannitol, and ethanol without bias.

After a vigorous shaking, $2 \mathrm{~mL}$ of the cell suspension was removed from the cell culture tubes and centrifuged at 10,000 rpm for $10 \mathrm{~min}$. The supernatants were filtered through a regenerated cellulose membrane (Roth-Sochiel, Lauterbourg, France with a pore diameter of $0.45 \mu \mathrm{m}$, and then kept frozen at $-20^{\circ} \mathrm{C}$ in glass vials (Fisher Scientific, Waltham, MA., USA) until HPLC (high performance liquid chromatography) analysis. The $\mathrm{OD}_{600}$ was measured for each strain in order to evaluate biomass production. The residual substrates (ethanol, lactic acid and mannitol) and metabolites (acetic acid) were quantified by high performance liquid chromatography (HPLC). The HPLC analysis was performed using an Aminex HPX-87H column (Biorad, Hemel Hempstead, UK, $300 \times 7.8$ mm), along with detection by both refractive index (for ethanol and mannitol) and UV absorption at $210 \mathrm{~nm}$ (lactic and acetic acid). The elution was performed at $30{ }^{\circ} \mathrm{C}$ with $5 \mathrm{mM}$ sulfuric acid at a flow rate of $0.6 \mathrm{~mL} / \mathrm{min}$. The biomass yield was calculated as follows: $\mathrm{Y}_{\mathrm{X} / \mathrm{S}}$ where $X$ is the biomass (OD) and $S$ substrates (ethanol and lactic acid) consumption in $\mathrm{mM}$ (value by HPLC). The conversion ratio of ethanol into acetic acid ( $\left.\mathrm{Y}_{\mathrm{AA} / \mathrm{EtOH}}\right)$ was calculated by dividing the moles of acetic acid produced by the moles of ethanol consumed. A conversion of 1 mole of acetic acid from 1 mole of ethanol $\left(\mathrm{Y}_{\mathrm{AA} / \mathrm{EtOH}}=1\right)$ was considered as the maximal stoichiometric ratio. The biomass yield, determined by the acetic acid produced, was defined as follows: $Y_{X / A A}, s$ where $X$ is the biomass $\left(\mathrm{OD}_{600}\right)$ and AA is the acetic acid production in $\mathrm{mM}$. The molar ratio $\left(\mathrm{R}_{\mathrm{LA} / \mathrm{EtOH}}\right)$ of lactic acid and ethanol consumption was also calculated in order to determine the relative affinity for ethanol and lactic acid as carbon sources for their growth and/or to produce acetic acid [48,49].

\subsubsection{Statistical Analysis}

All of the statistical analyses were performed using XLSTAT software v. 2019.1.3 (Addinsoft, Paris, France) and Rstudio (v. 1.1.453- C 2009-2018 RStudio, Inc., Boston, MA, USA). The box plots were developed in Excel, and the dendrogram and heatmap were developed in Rstudio. The preprocessing of the HPLC data consisted of the normalization on the biomass product (OD) to correct the inter-strain differences in consumption in lab-scale fermentation experiments. Then, conversion to Z-scores in order to correct noise was performed, calculated as followed: Z-score $=(X-\mu) / \sigma$, where $X$ is the value measurement, $\mu$ is the mean value of all of the strains, and $\sigma$ is the standard deviation of the values of all strains. A cluster analysis was performed using Euclidean distance for the building of the matrix and UPGMA (Unweighted pair group method with arithmetic mean) algorithm $[50,51]$. The statistical analysis tests were Shapiro-Wilk (normality test) and Kruskall-Wallis (one-way analysis of variance).

\subsection{Genomic Diversity Analysis of Acetobacter pasteurianus by Rep-PCR}

The genomic polymorphism of the AAB strains was analyzed by the $(\mathrm{GTG})_{5}$ amplification of the GTG repeated sequences (5' GTGGTGGTGGTGGTG 3'), as previously described 
by Versalovic et al. [52,53]. The PCR mixtures contained AmpliTaq Gold ${ }^{\mathrm{TM}} 360$ Master Mix reaction buffer $\left(1 \times\right.$, ThermoFisher ${ }^{\circledR}$, Waltham, MA, USA), $2 \mu$ M primer, $3.5 \%$ DMSO (diméthylsulfoxyde) (Sigma-Aldrich, Saint-Louis, MO, USA), and $1 \mu \mathrm{L}$ DNA $(10 \mathrm{ng} / \mu \mathrm{L})$ in a final volume of $50 \mu \mathrm{L}$. The amplification was carried out under the following conditions: an initial denaturation step at $95{ }^{\circ} \mathrm{C}$ for $3 \mathrm{~min}$, followed by 30 cycles at $90^{\circ} \mathrm{C}$ for $30 \mathrm{~s}, 42{ }^{\circ} \mathrm{C}$ for $30 \mathrm{~s}, 65^{\circ} \mathrm{C}$ for $4 \mathrm{~min}$, and a final elongation step at $65^{\circ} \mathrm{C}$ for $8 \mathrm{~min}$ [54]. The migration of the PCR amplicons was performed on $1.5 \%$ agarose gels containing $1 \times$ TAE (Tris Acetate EDTA) at 100 volts for $2 \mathrm{~h}$, and stained thereafter by DNA intercalant GelRed (Biotium, Brumath, France) for $1 \mathrm{~h}$ at the ambient temperature. The PCR products were loaded with size markers at both extremities of the gel in order to facilitate the normalization of the migration distances. The gels were visualized and photographed on a $312 \mathrm{~nm}$ UV transilluminator with a digital camera controlled by the software Gel Smart 7.3 (Clara Vision, Bièvres, France). The amplifications were realized in duplicates, and the PCR products were deposited randomly in the gels in order to eliminate a potential gel variation effect. The normalization of the migration distance (Rf) between the electrophoresis gels was achieved using the CLIQS software (v. 1.2.0.044, Totallab, Newcastle-Upon-Tyne, UK). The (GTG)5 PCR banding patterns analysis was performed using CLIQS software, and the statistical analyses were performed with Rstudio (v. 1.1.453, () 2009-2018 RStudio, Inc., USA). In order to generate the (GTG) 5 PCR patterns for each strain, only the bands which were shared between the duplicates amplifications were kept and used for the statistical analyses. The distance matrices were calculated according to the Sørensen-Dice index (band presence or absence); a dendrogram was generated and a permutational multivariate analysis of variance (PERMANOVA) was performed.

\section{Results}

\subsection{Identification of the Acetic Acid Bacteria Strains by $16 S$ rRNA Gene Sequencing}

In total, 130 Gram-negative ellipsoidal bacilli were isolated on Kneifel medium. All of the strains were identified as acetic acid bacteria by $16 \mathrm{~S}$ rRNA gene sequencing with a percentage of identity higher than $98 \%$. These AAB strains were affiliated to Acetobacter $(n=122)$ and to the Gluconobacter $(n=8)$ genera (Table 2$)$.

Table 2. Molecular identification of the $130 \mathrm{AAB}$ strains by $16 \mathrm{~S}$ rRNA gene sequencing and the repartition of the isolates according to the three countries: Ivory Coast, French Guiana, and Mexico.

\begin{tabular}{|c|c|c|c|c|c|c|}
\hline \multirow[t]{2}{*}{$\begin{array}{l}\text { Bacterial Species } \\
\text { Identification }\end{array}$} & \multirow[t]{2}{*}{ Total Strains } & \multicolumn{2}{|c|}{ Ivory Coast } & \multirow[t]{2}{*}{ French Guiana } & \multicolumn{2}{|c|}{ Mexico } \\
\hline & & 2016 & 2018 & & Main & Mid Crop \\
\hline A. pasteurianus & $89 *$ & $24 *$ & 15 & 10 & 11 & 29 \\
\hline A. tropicalis & 16 & 5 & 2 & 2 & 5 & 2 \\
\hline A. fabarum & 2 & 1 & 1 & 0 & 0 & 0 \\
\hline A. ghanensis & 7 & 5 & 2 & 0 & 0 & 0 \\
\hline A. orientalis & 2 & 0 & 0 & 2 & 0 & 0 \\
\hline A. malorum/A. cerevisiae & 6 & 0 & 0 & 0 & 0 & 6 \\
\hline G. oxydans & 7 & 1 & 0 & 6 & 0 & 0 \\
\hline G. nephelii & 1 & 1 & 0 & 0 & 0 & 0 \\
\hline Sub-total & & 37 & 20 & & 16 & 37 \\
\hline Total strains & 130 & \multicolumn{2}{|c|}{57} & 20 & \multicolumn{2}{|c|}{53} \\
\hline
\end{tabular}

* three with a percentage identity lower than $98.7 \%$, not included in the following analyses.

Among the Acetobacter strains, A. pasteurianus was the most recovered species, with $73.4 \%$ of the isolates, followed by A. tropicalis, Acetobacter ghanensis, A. fabarum, and A. orientalis, which represented, respectively, $13 \%, 5.6 \%, 1.6 \%$, and $1.6 \%$ of the total Acetobacter isolates. Six Acetobacter strains could not be affiliated at the species level, because A. cerevisiae or A. malorum were very close genetically, and the $16 \mathrm{~S}$ rRNA gene sequence was not sufficient to differentiate them [55]. Among the Gluconobacter strains, Gluconobacter oxydans was the most encountered species, with $87.5 \%$, along with Gluconobacter nephelii, with $12.5 \%$ of the total of the Gluconobacter strains. The distribution of acetic acid bacteria strains according to 
the origin's countries shows that the A. pasteurianus and A. tropicalis strains were distributed over the three countries, while the $A$. fabarum and $A$. ghanensis strains were isolated only in Ivory Coast, A. orientalis were isolated only in French Guiana, and A. cerevisiae/malorum strains were isolated only in Mexico. Gluconobacter oxydans strains were isolated in Ivory Coast and French Guiana, and Gluconobacter nephelii only in Ivory Coast (Table 2).

Eighty-six (86) isolates were strongly assigned to the species $A$. pasteurianus, with a $16 \mathrm{~S}$ rRNA gene sequence identity value of $\geq 98.7 \%$ [56] (Table S1). The $16 \mathrm{~S}$ rRNA gene sequence phylogenic analysis revealed that the isolates were affiliated to the species $A$. pasteurianus and $A$. pomorum (Figure S1), with a bootstrap of $99 \%$. However, A. pomorum was in a clade separated from all of the $A$. pasteurianus strains. These two strains are known to represent an important $16 \mathrm{~S}$ rDNA sequence similarity $[57,58]$. A. pomorum strains are known to be involved in industrial vinegar production $[59,60]$, but are not known to be involved in cocoa fermentation, and were never isolated in it [61].

\subsection{Comparative Analysis of the A. pasteurianus Strains' Metabolism in a Medium Stimulating Cocoa Pulp}

According to the results of the strain identification by $16 \mathrm{~S}$ rRNA gene sequencing, A. pasteurianus was the most common species among the AAB isolates. The strains used for this analysis were numbered from 1 to 92, with the name codes CI, MX, and GF for Ivory Coast, Mexico, and French Guiana, respectively, and the Genbank accession numbers from MN909060 (CI1) to MN909151 (MX92) (Table S1). A. pasteurianus LMG 01262 ${ }^{\mathrm{T}}$ was also included for the analysis. The name codes for the three AAB from the other species were: A. tropicalis MX92, A. fabarum CI25, and G. oxydans GF51.In order to investigate the intraspecific diversity of the 86 strains of $A$. pasteurianus isolated from three regions of the world, their basic metabolism was studied in a medium simulating the cocoa pulp conditions during the fermentation process developed by Moens et al. [42]. Different parameters were calculated from the substrate consumption and acetic acid production demonstrated by HPLC: the biomass yield $\left(\mathrm{Y}_{\mathrm{X} / \mathrm{S}}\right)$ to determine the biomass productivity, the production yield of ethanol into acetic acid $\left(\mathrm{Y}_{\mathrm{AA} / \mathrm{EtOH}}\right)$, and the biomass yield produced by the acetic acid produced $\left(\mathrm{Y}_{\mathrm{X} / \mathrm{AA}}\right)$. The lactic acid/ethanol ratio $\left(\mathrm{R}_{\mathrm{LA} / \mathrm{EtOH}}\right)$ was also calculated in order to determine the relative affinity for ethanol and lactic acid as carbon sources for their growth and/or to produce acetic acid. These different parameters were used together with the specific growth $(\mu)$ rate in order to compare the strains. An overview is shown in the dendrogram (Figure 1). 


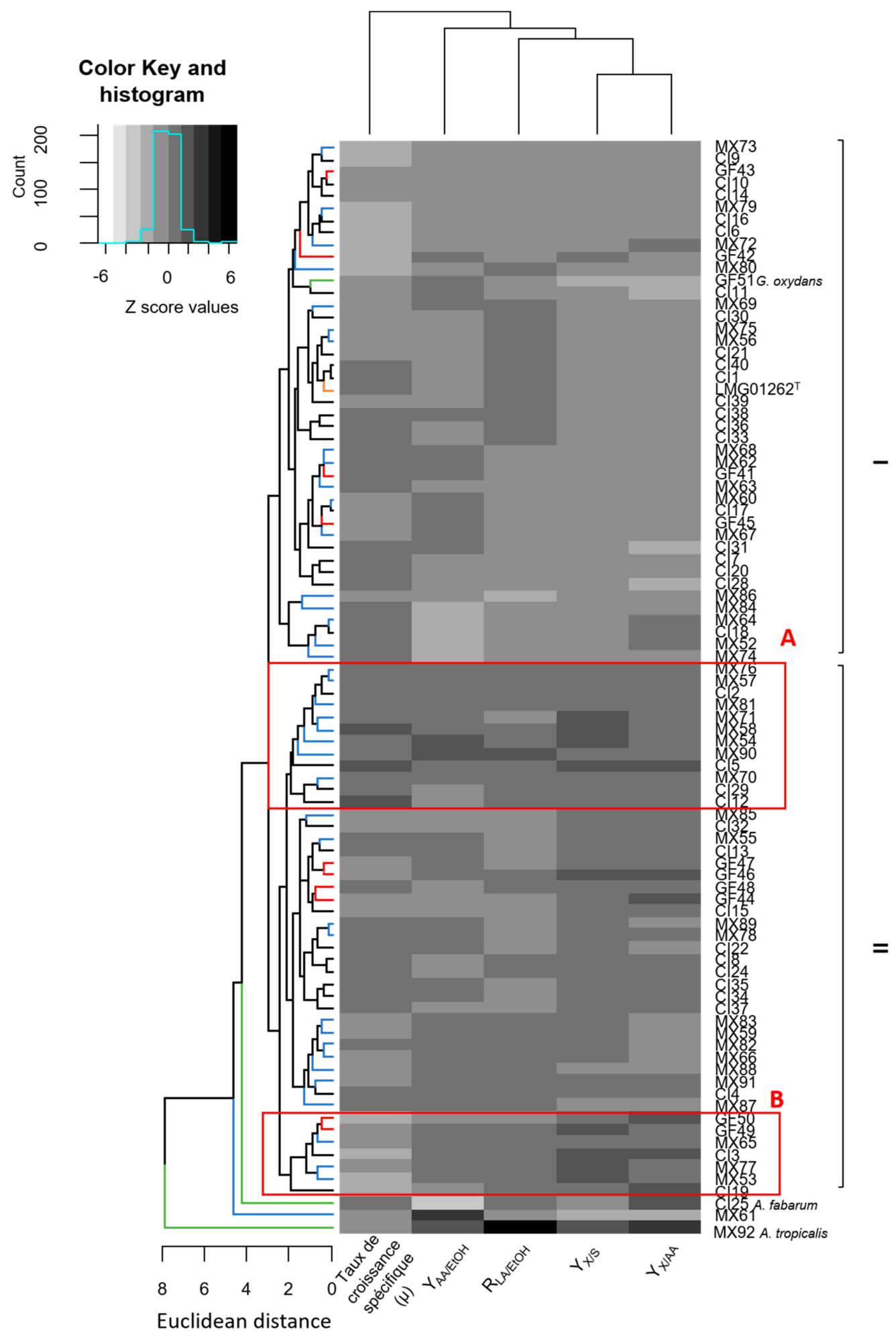

Figure 1. Biochemical relatedness of the 86 Acetobacter pasteurianus strains, the A. pasteurianus-type strain, and the $3 \mathrm{AAB}$. The measurements were converted into Z-scores, pairwise similarities were calculated by Euclidean distance, and an UGPMA clustering algorithm was applied in order to cluster the data. With the $\mathrm{Y}_{\mathrm{EtOH} / \mathrm{AA}}=$ conversion efficiency of ethanol into acetic acid, $\mathrm{R}_{\mathrm{LA} / \mathrm{EtOH}}=$ correspond to the lactic acid consumption divided by the ethanol consumption, $\mathrm{Y}_{\mathrm{X} / \mathrm{S}}=$ biomass yield, $\mathrm{Y}_{\mathrm{X} / \mathrm{AA}}=$ biomass yield produced by acetic acid produced, and specific growth rate $(\mu)$. $\mathrm{X}$ was the biomass, $\mathrm{S}=$ substrates consumption, $\mathrm{LA}=$ lactic acid, $\mathrm{AA}=$ acetic acid, and $\mathrm{EtOH}=$ ethanol. The tree branches were colored according to the strain origin: Mexico (blue), Ivory Coast (black), French Guiana (red), type strain (brown), and the three other AAB species in green. The red squares are the two subsclusters containing interesting strains. 


\subsubsection{Dendrogram and Heatmap Analysis}

The strains were compared using their Z-scores. According to the histogram of the Z-score data (Figure 1), most of the Z-score data were grouped between -1 and 1, indicating a strong similarity between the strains. In order to evaluate the influence of the geographical origin and fermentation time on the strain clustering, statistical tests were performed by the variance analysis of the Euclidean distance matrices. It appeared that the origin country had a significant effect on the clustering $\left(p\right.$-value $\left.=0.028^{*}\right)$, while the fermentation day did not ( $p$-value $>0.05)$.

The A. pasteurianus strains were clustered into two large clusters with a strong similarity between strains (Euclidean distance less than two on a scale of eight) (Figure 1). The repartition of the strains according to their origin in each cluster is detailed in Table 3.

Table 3. Clustering of the A. pasteurianus strains according to their physiological traits.

\begin{tabular}{|c|c|c|c|}
\hline $\begin{array}{c}\text { Metabolism } \\
\text { Group }\end{array}$ & $\begin{array}{l}\text { Isolates } \\
\text { Number }\end{array}$ & Isolates & Origin Country \\
\hline $\mathbf{I}$ & 42 & $\begin{array}{l}\text { LMG01262 }{ }^{\mathrm{T}} \text {; CI1; CI10; CI11; } \\
\text { CI14; CI16; CI17; CI18; CI20; } \\
\text { CI21;CI28; CI30; CI31; CI33; } \\
\text { CI36; CI38; CI39; CI40; CI6; } \\
\text { CI7; CI9; GF41; GF42; GF43; } \\
\text { GF45; MX52; MX56; MX60; } \\
\text { MX62; MX63; MX64; MX67; } \\
\text { MX68; MX69; MX72; MX73; } \\
\text { MX74; MX75; MX79; MX80; } \\
\quad \text { MX84; MX86; GF51 }\end{array}$ & $\begin{array}{c}\text { Ivory Coast }\left(20 / 36,55.5 \%{ }^{*}\right) \\
\text { Mexico }\left(17 / 40,42.5 \%{ }^{*}\right), \\
\text { and French Guiana }\left(4 / 10,40 \%{ }^{*}\right)\end{array}$ \\
\hline II & 44 & $\begin{array}{l}\text { CI12; CI13; CI15; CI19; CI2; } \\
\text { CI22; CI24; CI29; CI3; CI32; } \\
\text { CI34; CI35; CI37; CI4; CI5; } \\
\text { CI8; GF44; GF46; GF47; GF48; } \\
\text { GF49; GF50; MX53; MX54; } \\
\text { MX55; MX57; MX58; MX59; } \\
\text { MX65; MX66; MX70; MX71; } \\
\text { MX76; MX77; MX78; MX81; } \\
\text { MX82; MX83; MX85; MX87; } \\
\text { MX88; MX89; MX90; MX91 }\end{array}$ & $\begin{array}{c}\text { Mexico }(22 / 40,55 \% *) \text {, Ivory } \\
\text { Coast }(16 / 36,44.5 \% *) \text {, French } \\
\text { Guiana }(6 / 10,60 \% *)\end{array}$ \\
\hline
\end{tabular}

Cluster I was composed of 42 strains with 20 isolates from Ivory Coast (55.5\% of the Ivorian strains), 17 isolates from Mexico ( $42.5 \%$ of the Mexican strains), four strains from French Guiana ( $40 \%$ of the Guyanese strains), A pasteurianus $\mathrm{LMG} 01262^{\mathrm{T}}$ and G. oxydans strain (GF51). The moderates $\mathrm{Y}_{\mathrm{X} / \mathrm{S}}, \mathrm{Y}_{\mathrm{X} / \mathrm{AA}}$, and the conversion efficiency of ethanol into acetic acid were observed for the strains belonging to this cluster. Cluster II was composed of 44 strains, with 22 from Mexico (55\% of the Mexican strains), 16 isolates from Ivory Coast (44.5\% of the Ivorian strains), and 6 from French Guiana (60\% of the Guyanese strains). The strains in this cluster were characterized by higher $\mathrm{Y}_{\mathrm{AA} / \mathrm{EtOH}}, \mathrm{R}_{\mathrm{LA} / \mathrm{EtOH}}$, $\mathrm{Y}_{\mathrm{X} / \mathrm{S}}$, and $\mathrm{Y}_{\mathrm{X} / \mathrm{AA}}$ than the other strains. Strain MX61 was not clustered with the other A. pasteurianus, and presented the highest $\mathrm{Y}_{\mathrm{AA} / \mathrm{EtOH}}$, with low $\mathrm{Y}_{\mathrm{X} / \mathrm{S}}$, and $\mathrm{Y}_{\mathrm{X} / \mathrm{AA}}$ values compared to the other strains. A. fabarum $\mathrm{CI} 25$ and A. tropicalis MX92 were not clustered with the A. pasteurianus strains. A. fabarum had a lower conversion efficiency of ethanol in acetic acid than $A$. tropicalis. The latter is characterized by high $\mathrm{R}_{\mathrm{LA} / \mathrm{EtOH}}$ and $\mathrm{Y}_{\mathrm{X} / \mathrm{AA}}$ compared to the $A$. pasteurianus strains. 
3.2.2. Comparison of the Molecule Consumption and Production between the Strain Clusters

Most of the strains did not consume or negligibly consumed the mannitol present in the medium in our experimental conditions ( 0 to $10 \mathrm{mM}$ Optical Density Units, ODU, data not shown). Thus, it was not considered in the comparative analysis of the clusters. In order to identify the parameters which had a significant effect within each cluster, a two-by-two analysis was performed. All of the selected parameters except for the specific growth rate participated in the clustering ( $p$-value $\left.<0.0001^{* * *}\right)$. The strains from cluster I exhibited lower values for $\mathrm{Y}_{\mathrm{X} / \mathrm{S}}$ (median $=9.38 \mathrm{ODU} / \mathrm{mol}$ ) and $\mathrm{Y}_{\mathrm{X} / \mathrm{AA}}$ (median $=17.5 \mathrm{ODU} / \mathrm{mol}$ ) than the strains in cluster II, with $\mathrm{Y}_{\mathrm{X} / \mathrm{S}}$ (median=19.35 ODU $/ \mathrm{mol}$ ) and $\mathrm{Y}_{\mathrm{X} / \mathrm{AA}}$ (median $=31 \mathrm{ODU} / \mathrm{mol}$ ) (Figure 2$)$. Both clusters had a very high conversion efficiency of ethanol into acetic acid $\left(\mathrm{Y}_{\mathrm{AA} / \mathrm{EtOH}}\right)$ : cluster $\mathrm{I}=0.83$, and cluster $\mathrm{II}=0.94$ median value; cluster II had a higher $\mathrm{Y}_{\mathrm{AA} / \mathrm{EtOH}}$, explained by strains which had a value higher than 1; while in cluster I, the strains had a value less than 0.5 (Figure 2).
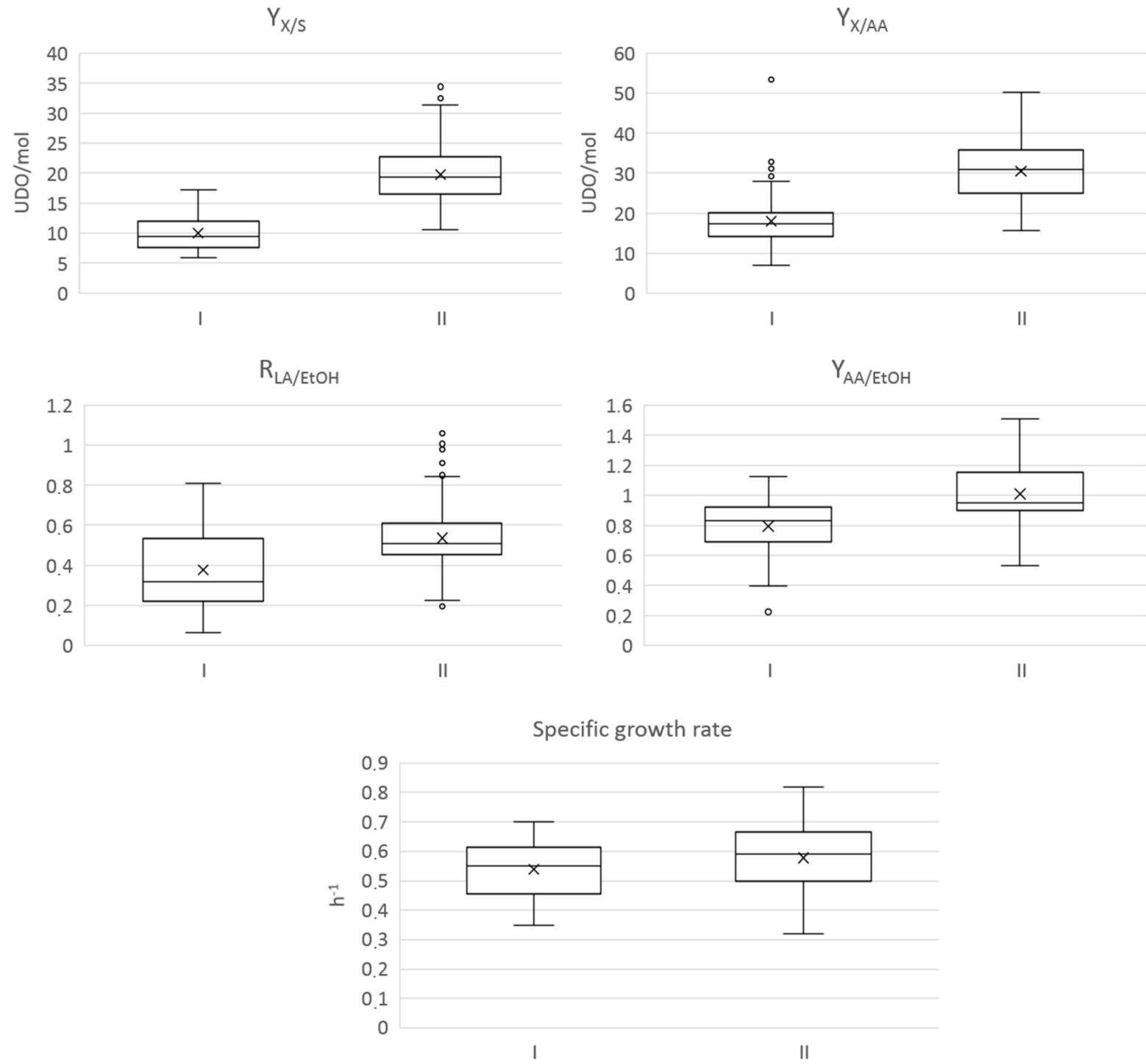

Figure 2. Comparisons in boxplots of the physiological traits of Acetobacter pasteurianus strains from different geographical origins and one type of strain according to the two large clusters. $\mathrm{Y}_{\mathrm{EtOH} / \mathrm{AA}}=$ conversion efficiency of ethanol into acetic acid, $\mathrm{R}_{\mathrm{LA} / \mathrm{EtOH}}=$ the lactic acid consumption divided by the ethanol consumption, $\mathrm{Y}_{\mathrm{X} / \mathrm{S}}=$ biomass yield, $\mathrm{Y}_{\mathrm{X} / \mathrm{AA}}=$ biomass yield produced by the acetic acid produced and the specific growth rate in $h^{-1}$. Where $X$ is the biomass, $S=$ substrates consumption, $\mathrm{LA}=$ lactic acid, $\mathrm{AA}=$ acetic acid. $\mathrm{EtOH}=$ ethanol. 
Both clusters had a preference for ethanol over lactic acid; indeed, their $\mathrm{R}_{\mathrm{AL} / \mathrm{EtOH}}$ were less than 1 . However, the strains in cluster II had higher $\mathrm{R}_{\mathrm{LA} / \mathrm{EtOH}}$, with a median value of 0.5 , while cluster I had a median $\mathrm{R}_{\mathrm{LA} / \mathrm{EtOH}}$ of 0.31 . The analysis of the ethanol and lactic acid specific consumption of the 86 A. pasteurianus strains confirmed that they generally consumed more ethanol than lactic acid, ranging between $25.58^{ \pm 3.49}$ and $132.15^{ \pm 8.34}$ $\mathrm{mM} / \mathrm{ODU}$, and $7.5^{ \pm 0.79}$ and $56.71^{ \pm 5.07} \mathrm{mM} / \mathrm{ODU}$, respectively (mean value taken for each strain) (Figure S2). Regarding the specific growth rate, the median value for each cluster was around $0.6 \mathrm{~h}^{-1}$, and the statistical tests showed a non-significant difference between the clusters with a $p$-value of 0.091. Finally, two subsclusters in cluster II, cluster II-A and cluster II-B, appeared to have a higher preference for lactic acid, with a high $\mathrm{Y}_{\mathrm{AA} / \mathrm{EtOH}}$ (Figure 1). The ratio $\mathrm{R}_{\mathrm{LA} / \mathrm{EtOH}}$ was higher than the strains in cluster I (cluster II-A $=0.61$ and cluster II-B $=0.5$ ) with the strains which had a $\mathrm{R}_{\mathrm{LA} / \mathrm{EtOH}}$ equal or close to 1 , such as MX90, CI19, and MX81; these three strains also had a $\mathrm{Y}_{\mathrm{AA} / \mathrm{EtOH}}$ close to or higher than 1 . These sub clusters had also a great biomass productivity, resulting in a higher yield of acetic acid. Cluster II-A was composed of seven Mexican strains and two Ivorian strains, and cluster II-B was composed of three Mexican strains, two Guyanese strains, and two Ivorian strains.

\subsection{Genomic Polymorphism Analysis of the Acetic Acid Bacteria by (GTG) ${ }_{5}$ PCR}

We further analyzed the genomic polymorphism of 86 A. pasteurianus strains using one single oligonucleotide primer (GTG) 5 with three other AAB strains: A. tropicalis, A. fabarum, and G. oxydans. The strains used for this analysis were numbered from 1 to 92 , with the name codes CI, MX, and GF for Ivory Coast, Mexico, and French Guiana, respectively, and the Genbank accession numbers from MN909060 (CI1) to MN909151 (MX92) (Table S1). A. pasteurianus LMG $01262^{\mathrm{T}}$ was also included for the analysis. The name codes for the three AAB from the other species were: A. tropicalis MX92, A. fabarum CI25, and G. oxydans GF51.

After the amplification and gel electrophoresis, the banding patterns contained between 7 to 23 DNA fragments ranging from 350 to $3000 \mathrm{bp}$. Visually, all of the banding patterns of the A. pasteurianus strains shared several bands at 350, 380, 480, 1100, and $1250 \mathrm{bp}$ (Figure 3). The results of the numerical and statistical analysis of the generated (GTG) PCR banding patterns are shown in the dendrogram (Figure 3). 


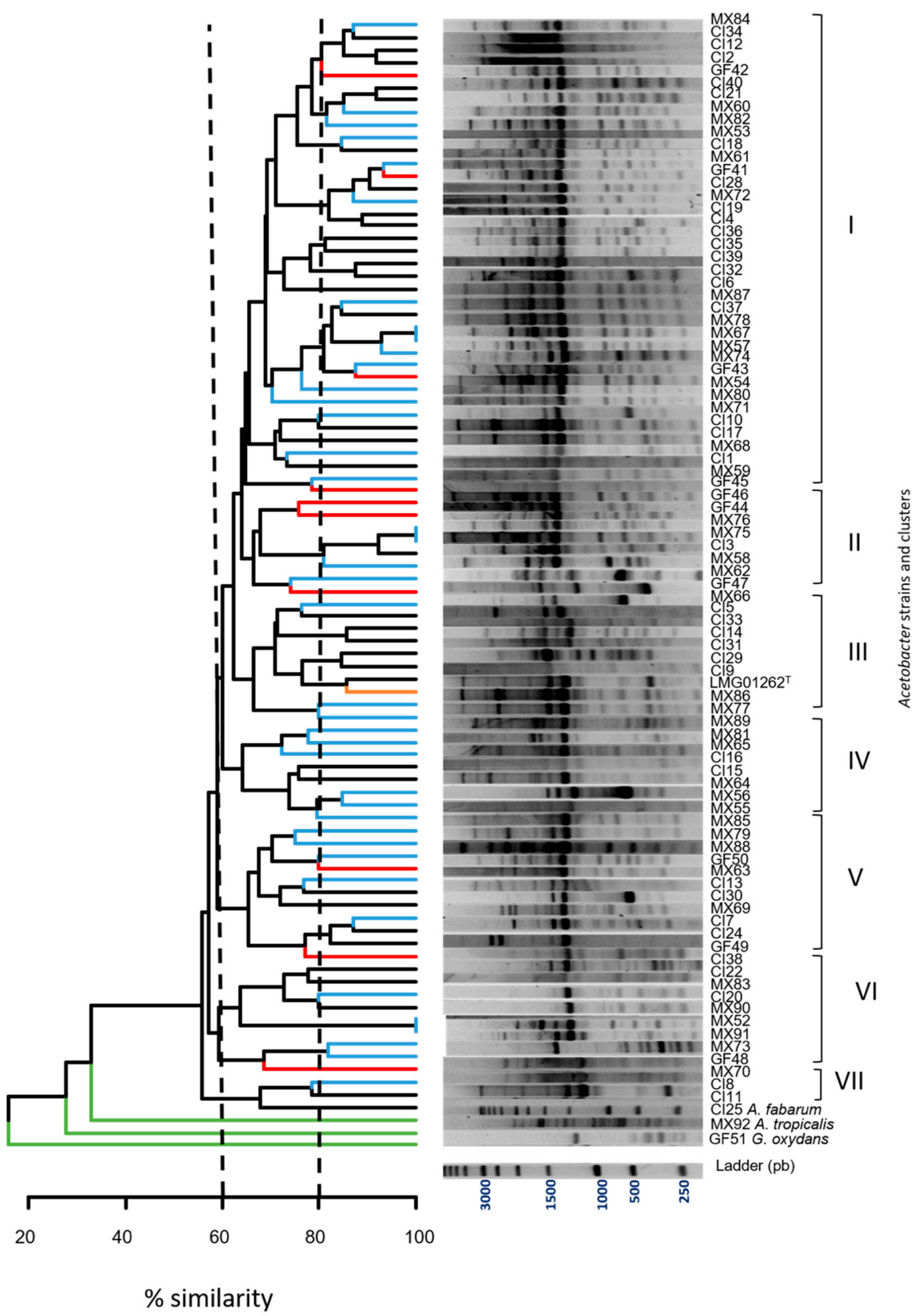

Figure 3. (GTG) $)_{5}$ PCR banding patterns and the dendrogram generated after the statistical analysis of the similarity of the banding patterns of the 86 Acetobacter pasteurianus, and three AAB-Acetobacter fabarum, Acetobacter tropicalis and Gluconobacter oxydans - strains isolated from spontaneous cocoa fermentations in three areas around the world, and one A. pasteurianus-type strain $\left(\mathrm{LMG} 0162^{\mathrm{T}}\right)$. The Sørensen-Dice index was used to analyze the similarity, and a UGPMA clustering algorithm was applied to cluster the data. The tree branch colour code is identical to that in Figure 1. 
All of the A. pasteurianus strains were clustered into seven groups (I to VII, Table 4) with a minimum of $60 \%$ similarity, and all of the clusters contained strains from at least two countries.

Table 4. Clustering of $A$. pasteurianus strains according to the genomic polymorphism analysis by (GTG) ${ }_{5}$ PCR.

\begin{tabular}{|c|c|c|c|c|}
\hline (GTG)5 Grouping & Isolates Number & $\%$ Clustering & Isolates & Origin Country \\
\hline $\mathbf{I}$ & 38 & $62.5 \%$ & $\begin{array}{l}\text { MX84; CI34; CI12; CI2; GF42; CI40; } \\
\text { CI21; MX60; MX82; MX53; CI18; } \\
\text { MX61; GF41; CI28; MX72; CI19; CI4; } \\
\text { CI36; CI35; CI39; CI32; CI6; MX87; } \\
\text { CI37; MX78; MX67; MX57; MX74; } \\
\text { GF43; MX54; MX80; MX71; CI10; } \\
\text { CI17; MX68; CI1; MX59; GF45 }\end{array}$ & $\begin{array}{l}\text { Mexico }(40 \% *) \text {, Ivory } \\
\text { Coast }(50 \% *) \text {, French } \\
\text { Guiana }(30 \% *)\end{array}$ \\
\hline II & 8 & $65 \%$ & $\begin{array}{l}\text { GF46; GF44; MX76; MX75; CI3; } \\
\text { MX58; MX62; GF47 }\end{array}$ & $\begin{array}{c}\text { Mexico }(10 \% *) \text {, French } \\
\text { Guiana }(30 \% *) \text {, Ivory } \\
\text { Coast }(3 \% *)\end{array}$ \\
\hline III & 10 & $70 \%$ & $\begin{array}{l}\text { MX66; CI5; CI33; CI14; CI31; CI29; } \\
\text { CI9; LMG01262T; MX86; MX77 }\end{array}$ & $\begin{array}{l}\text { Ivory Coast }(17 \% *) \\
\text { Mexico }(7.5 \% *)\end{array}$ \\
\hline IV & 8 & $65 \%$ & $\begin{array}{l}\text { MX80; MX81; MX65; CI16; CI15; } \\
\text { MX64; MX56; MX55 }\end{array}$ & $\begin{array}{l}\text { Mexico }(15 \% *), \text { Ivory } \\
\text { Coast }(5.5 \% *)\end{array}$ \\
\hline $\mathbf{V}$ & 11 & $70 \%$ & $\begin{array}{l}\text { MX85; MX79; MX88; GF50; MX63; } \\
\text { CI13; CI30; MX69; CI7; CI24; GF49 }\end{array}$ & $\begin{array}{l}\text { Mexico }(12.5 \% *) \text {, Ivory } \\
\text { Coast }\left(11 \%{ }^{*}\right), \text { French } \\
\text { Guiana }(20 \% *)\end{array}$ \\
\hline VI & 9 & $60 \%$ & $\begin{array}{l}\text { CI38; CI22; MX83; CI20; MX90; } \\
\text { MX52; MX91; MX73; GF48 }\end{array}$ & $\begin{array}{c}\text { Mexico }(12.5 \% *) \text {, Ivory } \\
\text { Coast }(8 \% *), \text { French } \\
\text { Guiana }(10 \% *)\end{array}$ \\
\hline VII & 3 & $70 \%$ & MX70; CI8; CI11 & $\begin{array}{c}\text { Mexico }\left(2.5 \%{ }^{*}\right), \text { Ivory } \\
\text { Coast }\left(5.5 \%{ }^{*}\right)\end{array}$ \\
\hline
\end{tabular}

* Percentage is the number of strains of the country in the cluster divided by total number of strains from this country.

The majority of the strains were clustered into six clusters, with a variable number of isolates for each group: 38, 8, 10, 8, 11, and 9 isolates for clusters I, II, III, IV, V, and VI, respectively, with a similarity between clusters of $60 \%$ (Figure 3). In the A. pasteurianus clusters, most of the strains seems to be genetically closed, with a percentage of similarity around $80 \%$, indicating a low intraspecific genomic polymorphism. Furthermore, three strain pairs obtained 100\% similarity: MX75 and MX76 isolated in Mexico in the same fermentation time; MX90 and MX52, isolated in Mexico at two different fermentation times ( 4 and 5 days, respectively); and MX78 and MX67, isolated in Mexico at the same 3 days of fermentation, but in two different batches. Strains CI12 and CI2 were isolated at two fermentation times, and presented a similarity at 95\%. Strains CI40 and CI21, isolated at the same time of fermentation but in two different batches, also had a similarity of $95 \%$. Regarding these strains with high similarities (95\%), we can assume that they were the same strains isolated twice. On the other hand, other strain pairs, isolated in different countries, were clustered with a high percentage of similarity: $95 \%, 95 \%$, and $90 \%$ for CI27/GF42, MX61/GF41, and MX84/CI34, respectively. In addition, strain CI28 was clustered with the strain pair MX61/GF41 at 90\% similarity. All of these results indicate that strains could be found in two or three different countries.

The strains grouped in cluster VII showed 70\% similarity with the other cluster. It was composed of three strains: one isolated in Mexico (MX70) and two in Ivory Coast (CI8 and CI11). As expected, the three non-A. pasteurianus strains-CI25, MX92, and GF51-were clustered far from the A. pasteurianus strains, and showed less than $35 \%$ similarity. A. fabarum being the closest relative and G. oxydans the most distant to the A. pasteurianus strains. 
In order to evaluate the influence of the strains' origin countries or the fermentation day of strain isolation on the clustering, statistical tests were performed by analyzing their variance using distance matrices created with the Sørensen-Dice index. It appeared that the origin country had a strong effect on the clustering $\left(p\right.$-value $\left.=0.001^{* *}\right)$, while the fermentation day of strain isolation had not $(p$-value $>0.05)$. This effect was explained by the strains with high percentage of similarity $(>90 \%)$ which came from the same origin.

\section{Discussion}

All around the world, cocoa bean fermentations are mostly performed in a traditional way using a variety of production methods. This artisanal process leads to the variable organoleptic quality of the cocoa products. The development of a starter culture with mixed microorganisms has been proposed for successful fermentations for a final cocoa product with better quality and flavor. However, only a few published studies compared the intraspecific diversity of $A$. pasteurianus strains in order to develop starters which respect local biodiversity $[10,36]$. In order to preserve the bacterial biodiversity relative to a specific cocoa production area, it seemed interesting to investigate the intraspecific diversity of strains from different producing countries for the elaboration of starter cultures with optimal features.

Our results showed that $A$. pasteurianus was the most recovered species among $130 \mathrm{AAB}$ isolates, representing $69 \%$ of the strains. This observation confirms that the main $A A B$ species involved in spontaneous cocoa bean fermentations appeared to belong to A. pasteurianus, which is perfectly adapted to the cocoa environment with regard to its ability to oxidize the most substrate (ethanol, lactic acid, and mannitol), and its temperature and $\mathrm{pH}$ tolerance [6,61]. A first attempt to elucidate the intraspecific diversity was performed using strains from one origin country, Ghana $[10,36]$. The (GTG) 5 . fingerprinting and the analysis of their kinetics of growth, substrate consumption, and metabolite production were performed. Our study was a first attempt to elucidate the intraspecific diversity of a large panel of $A$. pasteurianus strains according to their geographical origins with genomic and metabolic intraspecific diversity analysis. The genomic polymorphism analysis with (GTG) 5 -rep-PCR showed a great similarity between the isolates from three countries, and according to the statistical tests, they were clustered according to their origin country. Papalexandratou et al. [62] also obtained banding patterns for Acetobacter pasteurianus strains using the different migration protocols of the PCR products. It was thus difficult to compare and correlate our profile with them.

Many studies have been performed aiming to elucidate the genomics and genetic polymorphisms of the A. pasteurianus strains involved in vinegar production. The chromosome sequence of 11 A. pasteurianus strains from vinegar fermentation and cocoa bean fermentation have been compared, and showed a high degree of homology [63]. These high homologies between the chromosomes of $A$. pasteurianus strains could explain the great similarities between the (GTG) 5 pattern profiles obtained for the isolates in our study. However, Illeghems et al. [34] found that $68 \%$ of the predicted proteins obtained by genome sequencing were shared between $A$. pasteurianus $386 \mathrm{~B}$, isolated from cocoa bean fermentation, and five other $A$. pasteurianus. Moreover, 27 genes were specific to the $386 \mathrm{~B}$ strain, and were probably linked to its unique performance in the cocoa fermentation process. These findings support the fact that high intraspecific metabolic diversity could be found among the $A$. pasteurianus species.

The main carbon sources for A. pasteurianus strains are ethanol and lactic acid. In our study, the analysis of the consumption of ethanol, lactic acid, and mannitol by several A. pasteurianus strains isolated in three different countries was performed. This phenotypic characterization remains of basic relevance to screen strains in selection strategies providing data to the cluster strains according to their convenient metabolic profile.

The kinetics experiments regarding metabolite consumption performed in our study showed that mannitol was not consumed until ethanol was completely exhausted and lactate remained in low quantity $(<2 \mathrm{~g} / \mathrm{L})$ (data not shown). This condition was never 
achieved in the experiments considered for this analysis (all OD600 $<3$, and ethanol remained in the medium). It has already been shown that $A$. pasteurianus usually oxidizes sugar very slowly until ethanol exhaustion $[42,64]$. Our experiments were performed on 86 strains, and confirmed this behavior regarding mannitol consumption. All of the A. pasteurianus strains studied here seemed to exhibit a stable phenotype regarding this feature. Most of the analyzed strains in our study showed a higher affinity for ethanol than lactic acid, with $\mathrm{R}_{\mathrm{LA} / \mathrm{EtOH}}$ being lower than 1, confirming the results of previous studies [36,42]. However, three strains of sub clusters cluster II-A and cluster II-B, MX90, CI19 and MX81, had a high yield of ethanol to acetic acid transformation, and appeared to have a higher affinity for lactic acid than the other strains. These strains could be interesting as a starter culture, because lactic acid is an undesirable metabolite in cocoa fermentation due to its unpleasant flavor [22]. Furthermore, these strains had a $\mathrm{Y}_{\mathrm{AA} / \mathrm{EtOH}}$ higher than 1, suggesting that their ethanol consumption alone cannot explain their acetic acid production. This finding highlights the potential significant involvement of lactic acid in acetic acid production by some strains of $A$. pasteurianus and $A$. tropicalis. The presence of the enzymes mandatory for the transformation of lactate to acetate through pyruvate and acetaldehyde by A. pasteurianus has been described [35]. Lactate has been shown to be mostly degraded through the tricarboxylic acid cycle (TCA), and through its oxidation to acetoin, but poorly to acetate [37]. However, the balance between these two pathways has been investigated on a single $A$. pasteurianus strain. Our results tend to show that this specificity may not be generalized to all A. pasteurianus strains. The strains in cluster I generally had $\mathrm{Y}_{\mathrm{AA} / \mathrm{EtOH}}$ lower than 1 , with some strains being beyond 0.5 . This finding suggests an over-oxidation of acetic acid produced from ethanol. Acetic acid over-oxidation has been reported to be provoked by an increased activity of the tricarboxylic acid (TCA) cycle enzymes and acetylCoA synthetase for energy supply. However, among acetic acid bacteria, the mechanism of switching between incomplete oxidation and assimilatory oxidation, and the control of energy and carbon metabolism remains poorly understood [37,64-66]. As acetic acid is a desirable product for the completeness of cocoa fermentation, acetic acid over-oxidation should be avoided in an AAB starter. This feature allows us to exclude strains in Cluster I in the choice of a culture starter.

For the three other $\mathrm{AAB}, \mathrm{G}$. oxydans was clustered with A. pasteurianus strains with a moderate $\mathrm{Y}_{\mathrm{AA} / \mathrm{EtOH}}$ and lower $\mathrm{Y}_{\mathrm{X} / \mathrm{AA}}$, explained by their slower ethanol oxidation than the A. pasteurianus strains $[67,68]$. A. tropicalis had an $\mathrm{Y}_{\mathrm{X} / \mathrm{AA}}$ higher than A. pasteurianus strains; lactic acid and ethanol oxidation have been reported to be effective in this strain [29]. The A. fabarum strain had a lower conversion efficiency of ethanol to acetic acid than the other strains, as demonstrated in a previous study [42].

The differences obtained by the biochemical analysis could be explained by the genetic instability of $A$. pasteurianus species. Genetic instability is known to occur at very high frequencies due to spontaneous mutations that cause the loss or acquisition of various physiological and phenotypic properties [63,69]. The genetic mechanisms which cause these instabilities are not fully understood, but according to [70,71] phenotypic modifications in ethanol oxidation can occur by the transposase insertion of a sequence element. The phenotypic variability of $A$. pasteurianus has been demonstrated on strains found in solid-state fermentation in vinegar technologies [72]. The 27 specific genes identified for A. pasteurianus 386B, as compared to other A. pasteurianus strains found by Illeghems et al. [34], also promote the idea that a metabolic diversity can be encountered in this species.

Our data indicated that the phenotypic information clustering was not related to the genomic clustering of $A$. pasteurianus strains. The analyses showed high genomic and phenotypic similarities between the strains; however, the multi-parametric clustering resulted in different groups. Some strains which were $100 \%$ identical according to (GTG) rep-PCR were not clustered together in the dendrogram based on their basic metabolism.

This finding suggests that (GTG) $)_{5}$ fingerprinting might not explain the variability among strains of Acetobacter pasteurianus, notably regarding their technological potential, such as their lactic acid and ethanol consumption. 
The strains with interesting characteristics (lactic acid consumption and no overoxidation of acetic acid) for a starter culture can be found in all of the origins; we can therefore select high-performance strains that are best adapted to the fermentation of cocoa from different origins.

\section{Conclusions}

The intraspecific analysis of strains isolated in three different countries around the world have been studied according to their genomic polymorphism, and their consumption and production of the main metabolites under cocoa-like conditions. The great similarity between strains indicated a low intraspecific diversity.

Genomic polymorphism was not correlated with the analysis of metabolic polymorphism, revealing that $(\mathrm{GTG})_{5}$-rep-PCR might not be sufficient for the differentiation of strains' metabolic features. In order to gain further information on AAB intraspecific diversity, a complementary method might be considered, such as whole genome sequencing (WGS) [34]. That method could allow us to highlight subtle differences between similar strains obtained with the $(\mathrm{GTG})_{5}$ fingerprinting method, and might help to establish correlations with the intraspecific biochemical diversity.

High ethanol conversion efficiency into acetic acid, and a high affinity for lactic acid could be used as selection criteria for AAB starter selection. Furthermore, the production of acetoin from lactic acid might help in understanding the diversity observed among A. pasteurianus species regarding their carbon metabolism. It will be interesting to compare their metabolic pathways using transcriptomics methods in order to study the expression of the genes involved in the conversion of lactate and ethanol into acetate [35], and coupled through the analysis of metabolic fluxes using labelled 13C isotope experiments [37].

Distant AAB metabolic profiles might be tested in cocoa fermentation at the lab scale in order to better understand the influence of $A$. pasteurianus metabolic diversity on the final quality of the cocoa product.

Supplementary Materials: The following are available online at https:/ /www.mdpi.com/2311-563 7/7/1/42/s1. Figure S1: Neighbor-joining tree based on nearly complete 16S rRNA gene sequences of $\mathrm{AAB}$ type strain and $\mathrm{AAB}$ isolated in this study. The robustness of the branching is indicated by bootstrap percentages calculated for 1000 subsets. Figure S2: Comparison of physiological traits of Acetobacter pasteurianus strains from different origins and the type strain LMG $01262^{\mathrm{T}}$, ethanol consumption, lactic acid consumption, acetic acid production in $\mathrm{mM} / \mathrm{OD}$. All values were normalized by biomass (OD600). For each strain, standard deviation was given. Figure S3: Example of growth curve obtained after the kinetic follow-up with the spectrophotometer. Table S1: Detailed list of Acetobacter strains used for genomic polymorphism and metabolic analysis.

Author Contributions: Conceptualization, L.F., A.C.d.I.N. and C.S.; Investigation, L.F.; Methodology, B.G. and J.G.; Project administration, C.T.; Resources, B.G., C.K. and J.G.; Supervision, D.M. and C.T.; Writing-original draft, L.F.; Writing—review \& editing, A.C.d.I.N., C.S., D.M. and C.T. All authors have read and agreed to the published version of the manuscript.

Funding: The sampling in Mexico was supported by DUFRENOY-Crédit Agricole d'Ile de France Mécénat grant.

Institutional Review Board Statement: Not applicable.

Informed Consent Statement: Not applicable.

Data Availability Statement: Publicly available datasets were analyzed in this study. This data can be found here: https: / / www.ncbi.nlm.nih.gov/nuccore/?term=MN909060:MN909151[accn] (accessed on 24 February 2021).

Acknowledgments: The data used in this work were partly produced through the GenSeq technical facilities of the Institut des Sciences de l'Evolution de Montpellier, with the support of LabEx CeMEB, an ANR 'Investissements d'avenir' program (ANR-10-LABX-04-01). The authors are grateful to Frenchoc Premium Project for the supporting samples. We would like to thank Guehi Tagro from 
Nangui Abrogoua University, Abidjan, Ivory Coast, Suárez Mirna Leonor and Hernández Medina Samuel from the technological institute of Veracruz, Mexico for providing the cocoa bean samples.

Conflicts of Interest: The authors declare that they have no conflict of interest.

\section{References}

1. Barel, M. Qualité du Cacao: L'impact du Traitement Post-Récolte; Quae Editions; Quae: Versailles, France, 2013; ISBN 978-2-7592-2052-6.

2. Ozturk, G.; Young, G.M. Food Evolution: The impact of society and science on the fermentation of cocoa beans. Compr. Rev. Food Sci. Food Saf. 2017, 16, 431-455. [CrossRef] [PubMed]

3. De Vuyst, L.; Weckx, S. The cocoa bean fermentation process: From ecosystem analysis to starter culture development. J. Appl. Microbiol. 2016, 121, 5-17. [CrossRef] [PubMed]

4. Schwan, R.F.; Wheals, A.E. The microbiology of cocoa fermentation and its role in chocolate quality. Crit. Rev. Food Sci. Nutr. 2004, 44, 205-221. [CrossRef] [PubMed]

5. Nielsen, D.S.; Teniola, O.D.; Ban-Koffi, L.; Owusu, M.; Andersson, T.S.; Holzapfel, W.H. The microbiology of Ghanaian cocoa fermentations analysed using culture-dependent and culture-independent methods. Int. J. Food Microbiol. 2007, 114, 168-186. [CrossRef] [PubMed]

6. Camu, N.; Gonzalez, A.; De Winter, T.; Van Schoor, A.; De Bruyne, K.; Vandamme, P.; Takrama, J.S.; Addo, S.K.; De Vuyst, L. Influence of turning and environmental contamination on the dynamics of populations of lactic acid and acetic acid bacteria involved in spontaneous cocoa bean heap fermentation in Ghana. Appl. Environ. Microbiol. 2008, 74, 86-98. [CrossRef]

7. Camu, N.; De Winter, T.; Verbrugghe, K.; Cleenwerck, I.; Vandamme, P.; Takrama, J.S.; Vancanneyt, M.; De Vuyst, L. Dynamics and biodiversity of populations of lactic acid bacteria and acetic acid bacteria involved in spontaneous heap fermentation of cocoa beans in Ghana. Appl. Environ. Microbiol. 2007, 73, 1809-1824. [CrossRef]

8. Daniel, H.M.; Vrancken, G.; Takrama, J.F.; Camu, N.; De Vos, P.; De Vuyst, L. Yeast diversity of Ghanaian cocoa bean heap fermentations. FEMS Yeast Res. 2009, 9, 774-783. [CrossRef]

9. Garcia-Armisen, T.; Papalexandratou, Z.; Hendryckx, H.; Camu, N.; Vrancken, G.; De Vuyst, L.; Cornelis, P. Diversity of the total bacterial community associated with Ghanaian and Brazilian cocoa bean fermentation samples as revealed by a $16 \mathrm{~S}$ rRNA gene clone library. Appl. Microbiol. Biotechnol. 2010, 87, 2281-2292. [CrossRef]

10. Lefeber, T.; Papalexandratou, Z.; Gobert, W.; Camu, N.; De Vuyst, L. On-farm implementation of a starter culture for improved cocoa bean fermentation and its influence on the flavour of chocolates produced thereof. Food Microbiol. 2012, 30, 379-392. [CrossRef]

11. Meersman, E.; Steensels, J.; Mathawan, M.; Wittocx, P.J.; Saels, V.; Struyf, N.; Bernaert, H.; Vrancken, G.; Verstrepen, K.J. Detailed analysis of the microbial population in Malaysian Spontaneous Cocoa Pulp Fermentations Reveals a Core and Variable Microbiota. PLoS ONE 2013, 8, e81559. [CrossRef]

12. Pettipher, G.L. Analysis of cocoa pulp and the formulation of a standardised artificial cocoa pulp medium. J. Sci. Food Agric. 1986, 37, 297-309. [CrossRef]

13. Papalexandratou, Z.; Lefeber, T.; Bahrim, B.; Lee, O.S.; Daniel, H.M.; De Vuyst, L. Hanseniaspora opuntiae, Saccharomyces cerevisiae, Lactobacillus fermentum, and Acetobacter pasteurianus predominate during well-performed Malaysian cocoa bean box fermentations, underlining the importance of these microbial species for a successful cocoa bean fermentation process. Food Microbiol. 2013, 35, 73-85. [CrossRef]

14. Papalexandratou, Z.; Vrancken, G.; De Bruyne, K.; Vandamme, P.; De Vuyst, L. Spontaneous organic cocoa bean box fermentations in Brazil are characterized by a restricted species diversity of lactic acid bacteria and acetic acid bacteria. Food Microbiol. 2011, 28, 1326-1338. [CrossRef] [PubMed]

15. Papalexandratou, Z.; Falony, G.; Romanens, E.; Jimenez, J.C.; Amores, F.; Daniel, H.M.; De Vuyst, L. Species diversity, community dynamics, and metabolite kinetics of the microbiota associated with traditional Ecuadorian spontaneous cocoa bean fermentations. Appl. Environ. Microbiol. 2011, 77, 7698-7714. [CrossRef]

16. Papalexandratou, Z.; Camu, N.; Falony, G.; De Vuyst, L. Comparison of the bacterial species diversity of spontaneous cocoa bean fermentations carried out at selected farms in Ivory Coast and Brazil. Food Microbiol. 2011, 28, 964-973. [CrossRef]

17. Ardhana, M. The microbial ecology of cocoa bean fermentations in Indonesia. Int. J. Food Microbiol. 2003, 86, 87-99. [CrossRef]

18. Crafack, M.; Mikkelsen, M.B.; Saerens, S.; Knudsen, M.; Blennow, A.; Lowor, S.; Takrama, J.; Swiegers, J.H.; Petersen, G.B.; Heimdal, H.; et al. Influencing cocoa flavour using Pichia kluyveri and Kluyveromyces marxianus in a defined mixed starter culture for cocoa fermentation. Int. J. Food Microbiol. 2013, 167, 103-116. [CrossRef] [PubMed]

19. Holm, C.S.; Aston, J.W.; Douglas, K. The effects of the organic acids in cocoa on the flavour of chocolate. J. Sci. Food Agric. 1993, 61, 65-71. [CrossRef]

20. John, W.A.; Kumari, N.; Böttcher, N.L.; Koffi, K.J.; Grimbs, S.; Vrancken, G.; D’Souza, R.N.; Kuhnert, N.; Ullrich, M.S. Aseptic artificial fermentation of cocoa beans can be fashioned to replicate the peptide profile of commercial cocoa bean fermentations. Food Res. Int. 2016, 89, 764-772. [CrossRef]

21. De Taeye, C.; Eyamo Evina, V.J.; Caullet, G.; Niemenak, N.; Collin, S. Fate of Anthocyanins through Cocoa Fermentation. Emergence of New Polyphenolic Dimers. J. Agric. Food Chem. 2016, 64, 8876-8885. [CrossRef] [PubMed]

22. Urbańska, B.; Derewiaka, D.; Lenart, A.; Kowalska, J. Changes in the composition and content of polyphenols in chocolate resulting from pre-treatment method of cocoa beans and technological process. Eur. Food Res. Technol. 2019, 245, 2101-2112. [CrossRef]

23. Hansen, C.E.; del Olmo, M.; Burri, C. Enzyme activities in cocoa beans during fermentation. J. Sci. Food Agric. 1998, 77, 273-281. [CrossRef] 
24. Teyssier, C.; Hamdouche, Y. Acetic Acid Bacteria. In Fermented Foods. Part I: Biochemistry and Biotechnology; CRC Press: Boca Raton, FL, USA, 2016; p. 97.

25. Sengun, I.Y.; Karabiyikli, S. Importance of acetic acid bacteria in food industry. Food Control 2011, 22, 647-656. [CrossRef]

26. De Roos, J.; De Vuyst, L. Acetic acid bacteria in fermented foods and beverages. Curr. Opin. Biotechnol. 2018, 49, 115-119. [CrossRef]

27. Bortolini, C.; Patrone, V.; Puglisi, E.; Morelli, L. Detailed analyses of the bacterial populations in processed cocoa beans of different geographic origin, subject to varied fermentation conditions. Int. J. Food Microbiol. 2016, 236, 98-106. [CrossRef]

28. De Melo Pereira, G.V.; Magalhães, K.T.; de Almeida, E.G.; da Silva Coelho, I.; Schwan, R.F. Spontaneous cocoa bean fermentation carried out in a novel-design stainless steel tank: Influence on the dynamics of microbial populations and physical-chemical properties. Int. J. Food Microbiol. 2013, 161, 121-133. [CrossRef]

29. De Melo Pereira, G.V.; Da Cruz Pedrozo Miguel, M.G.; Ramos Lacerda, C.; Schwan, R.F. Microbiological and physicochemical characterization of small-scale cocoa fermentations and screening of yeast and bacterial strains to develop a defined starter culture. Appl. Environ. Microbiol. 2012, 78, 5395-5405. [CrossRef]

30. De Melo Pereira, G.V.; Magalhães, K.T.; Schwan, R.F. rDNA-based DGGE analysis and electron microscopic observation of cocoa beans to monitor microbial diversity and distribution during the fermentation process. Food Res. Int. 2013, 53, 482-486. [CrossRef]

31. Hamdouche, Y.; Guehi, T.; Durand, N.; Kedjebo, K.B.D.; Montet, D.; Meile, J.C. Dynamics of microbial ecology during cocoa fermentation and drying: Towards the identification of molecular markers. Food Control 2015, 48, 117-122. [CrossRef]

32. De Vuyst, L.; Camu, N.; De Winter, T.; Vandemeulebroecke, K.; Van de Perre, V.; Vancanneyt, M.; De Vos, P.; Cleenwerck, I. Validation of the (GTG)5-rep-PCR fingerprinting technique for rapid classification and identification of acetic acid bacteria, with a focus on isolates from Ghanaian fermented cocoa beans. Int. J. Food Microbiol. 2008, 125, 79-90. [CrossRef] [PubMed]

33. Visintin, S.; Alessandria, V.; Valente, A.; Dolci, P.; Cocolin, L. Molecular identification and physiological characterization of yeasts, lactic acid bacteria and acetic acid bacteria isolated from heap and box cocoa bean fermentations in West Africa. Int. J. Food Microbiol. 2016, 216, 69-78. [CrossRef] [PubMed]

34. Illeghems, K.; De Vuyst, L.; Weckx, S. Complete genome sequence and comparative analysis of Acetobacter Pasteurianus 386B, a strain well-adapted to the cocoa bean fermentation ecosystem. BMC Genom. 2013, 14, 526. [CrossRef]

35. Sato, J.; Wakayama, M.; Takagi, K. Lactate dehydrogenase involved in lactate metabolism of Acetobacter pasteurianus. Procedia Environ. Sci. 2015, 28, 67-71. [CrossRef]

36. Lefeber, T.; Janssens, M.; Camu, N.; De Vuyst, L. Kinetic analysis of strains of lactic acid bacteria and acetic acid bacteria in cocoa pulp simulation media toward development of a starter culture for cocoa bean fermentation. Appl. Environ. Microbiol. 2010, 76, 7708-7716. [CrossRef]

37. Adler, P.; Frey, L.J.; Berger, A.; Bolten, C.J.; Hansen, C.E.; Wittmann, C. The key to acetate: Metabolic fluxes of acetic acid bacteria under cocoa pulp fermentation-simulating conditions. Appl. Environ. Microbiol. 2014, 80, 4702-4716. [CrossRef] [PubMed]

38. Crafack, M.; Keul, H.; Eskildsen, C.E.; Petersen, M.A.; Saerens, S.; Blennow, A.; Skovmand-Larsen, M.; Swiegers, J.H.; Petersen, G.B.; Heimdal, H.; et al. Impact of starter cultures and fermentation techniques on the volatile aroma and sensory profile of chocolate. Food Res. Int. 2014, 63, 306-316. [CrossRef]

39. Lefeber, T.; Janssens, M.; Moens, F.; Gobert, W.; De Vuyst, L. Interesting Starter Culture Strains for Controlled Cocoa Bean Fermentation Revealed by Simulated Cocoa Pulp Fermentations of Cocoa-Specific Lactic Acid Bacteria. Appl. Environ. Microbiol. 2011, 77, 6694-6698. [CrossRef] [PubMed]

40. Magalhães da Veiga Moreira, I.; de Figueiredo Vilela, L.; da Cruz Pedroso Miguel, M.; Santos, C.; Lima, N.; Freitas Schwan, R. Impact of a Microbial Cocktail Used as a Starter Culture on Cocoa Fermentation and Chocolate Flavor. Molecules 2017, 22, 766. [CrossRef]

41. Organisme International de la Vigne et du vin: Recueil des Méthodes Internationales D’analyses, Analyse Microbiologique des vins et des Moûts: Détection, Différenciation et Dénombrement des Microorganismes 2010. Available online: https: / / www.oiv.int/fr/technical-standards-and-documents / methods-of-analysis / compendium-of-international-methodsof-analysis-of-wines-and-musts-2-vol (accessed on 24 February 2021).

42. Moens, F.; Lefeber, T.; De Vuyst, L. Oxidation of metabolites highlights the microbial interactions and Role of Acetobacter pasteurianus during cocoa bean fermentation. Appl. Environ. Microbiol. 2014, 80, 1848-1857. [CrossRef]

43. Teyssier, C.; Marchandin, H.; Simeon De Buochberg, M.; Ramuz, M.; Jumas-Bilak, E. Atypical 16S rRNA gene copies in Ochrobactrum intermedium strains reveal a large genomic rearrangement by recombination between rrn copies. J. Bacteriol. 2003, 185, 2901-2909. [CrossRef]

44. Tulini, F.L.; Winkelströter, L.K.; De Martinis, E.C.P. Identification and evaluation of the probiotic potential of Lactobacillus paraplantarum FT259, a bacteriocinogenic strain isolated from Brazilian semi-hard artisanal cheese. Anaerobe 2013, 22, 57-63. [CrossRef]

45. Altschul, S. Gapped BLAST and PSI-BLAST: A new generation of protein database search programs. Nucleic Acids Res. 1997, 25, 3389-3402. [CrossRef] [PubMed]

46. Saitou, N.; Nei, M. The neighbor-joining method: A new method for reconstructing phylogenetic trees. Mol Biol Evol 1987, 4 , 406-425. [CrossRef]

47. Felsenstein, J. Confidence limits on phylogenies: An approch using the bootstrap. Evolution 1985, 39, 783-791. [CrossRef] [PubMed]

48. Alfenore, S.; Molina-Jouve, C.; Guillouet, S.; Uribelarrea, J.-L.; Goma, G.; Benbadis, L. Improving ethanol production and viability of Saccharomyces cerevisiae by a vitamin feeding strategy during fed-batch process. Appl. Microbiol. Biotechnol. 2002, 60, 67-72. [CrossRef]

49. Bailey, J.E.; Ollis, D.F. Biochemical Engineering Fundamentals, 2nd ed.; McGraw-Hill Chemical Engineering Series; McGraw-Hill: New York, NY, USA, 1986; ISBN 978-0-07-003212-5. 
50. Steensels, J.; Meersman, E.; Snoek, T.; Saels, V.; Verstrepen, K.J. Large-Scale Selection and Breeding to generate industrial yeasts with superior aroma production. Appl. Environ. Microbiol. 2014, 80, 6965-6975. [CrossRef]

51. Brase, C.H. Understanding Basic Statistics, 8th ed; Cengage Learning, Inc.: Boston, MA, USA, 2017; ISBN 978-1-337-55807-5.

52. Versalovic, J.; Koeuth, T.; Lupski, R. Distribution of repetitive DNA sequences in eubacteria and application to fingerprinting of bacterial genomes. Nucleic Acids Res. 1991, 19, 6823-6831. [CrossRef]

53. Versalovic, J.; Schneider, M.; de Bruijn, F.; Lupski, J. Genomic fingerprinting of bacteria using repetitive sequence-based polymerase chain reaction. Methods Mol. Cell. Biol. 1994, 5, 25-40.

54. Gonzalez, A.; Hierro, N.; Poblet, M.; Rozes, N.; Mas, A.; Guillamon, J.M. Application of molecular methods for the differentiation of acetic acid bacteria in a red wine fermentation. J. Appl. Microbiol. 2004, 96, 853-860. [CrossRef]

55. Valera, M.J.; Torija, M.J.; Mas, A.; Mateo, E. Acetobacter malorum and Acetobacter cerevisiae identification and quantification by Real-Time PCR with TaqMan-MGB probes. Food Microbiol. 2013, 36, 30-39. [CrossRef]

56. Ramasamy, D.; Mishra, A.K.; Lagier, J.-C.; Padhmanabhan, R.; Rossi, M.; Sentausa, E.; Raoult, D.; Fournier, P.-E. A polyphasic strategy incorporating genomic data for the taxonomic description of novel bacterial species. Int. J. Syst. Evol. Microbiol. 2014, 64, 384-391. [CrossRef]

57. Cleenwerck, I.; Camu, N.; Engelbeen, K.; De Winter, T.; Vandemeulebroecke, K.; De Vos, P.; De Vuyst, L. Acetobacter ghanensis sp. nov., a novel acetic acid bacterium isolated from traditional heap fermentations of Ghanaian cocoa beans. Int. J. Syst. Evol. Microbiol. 2007, 57, 1647-1652. [CrossRef]

58. Cleenwerck, I.; Gonzalez, A.; Camu, N.; Engelbeen, K.; De Vos, P.; De Vuyst, L. Acetobacter fabarum sp. nov., an acetic acid bacterium from a Ghanaian cocoa bean heap fermentation. Int. J. Syst. Evol. Microbiol. 2008, 58, 2180-2185. [CrossRef]

59. Sokollek, S.J.; Hertel, C.; Hammes, W.P. Description of Acetobacter oboediens sp. nov. and Acetobacter pomorum sp. nov., two new species isolated from industrial vinegar fermentations. Int. J. Syst. Bacteriol. 1998, 48, 935-940. [CrossRef]

60. Baek, C.H.; Park, E.H.; Baek, S.Y.; Jeong, S.T.; Kim, M.D.; Kwon, J.-H.; Jeong, Y.J.; Yeo, S.H. Characterization of Acetobacter pomorum KJY8 Isolated from Korean Traditional Vinegar. J. Microbiol. Biotechnol. 2014, 24, 1679-1684. [CrossRef]

61. Figueroa-Hernández, C.; Mota-Gutierrez, J.; Ferrocino, I.; Hernández-Estrada, Z.J.; González-Ríos, O.; Cocolin, L.; Suárez-Quiroz, M.L. The challenges and perspectives of the selection of starter cultures for fermented cocoa beans. Int. J. Food Microbiol. 2019, 301, 41-50. [CrossRef]

62. Papalexandratou, Z.; Cleenwerck, I.; De Vos, P.; De Vuyst, L. (GTG)5 -PCR reference framework for acetic acid bacteria. FEMS Microbiol. Lett. 2009, 301, 44-49. [CrossRef]

63. Azuma, Y.; Hosoyama, A.; Matsutani, M.; Furuya, N.; Horikawa, H.; Harada, T.; Hirakawa, H.; Kuhara, S.; Matsushita, K.; Fujita, N.; et al. Whole-genome analyses reveal genetic instability of Acetobacter pasteurianus. Nucleic Acids Res. 2009, 37, 5768-5783. [CrossRef]

64. Wu, J.; Gullo, M.; Chen, F.; Giudici, P. Diversity of Acetobacter pasteurianus strains isolated from solid-state fermentation of cereal vinegars. Curr. Microbiol. 2010, 60, 280-286. [CrossRef] [PubMed]

65. Sakurai, K.; Arai, H.; Ishii, M.; Igarashi, Y. Transcriptome response to different carbon sources in Acetobacter aceti. Microbiology 2011, 157, 899-910. [CrossRef]

66. Saeki, A.; Matsushita, K.; Takeno, S.; Taniguchi, M.; Toyama, H.; Theeragool, G.; Lotong, N.; Adachi, O. Enzymes responsible for acetate oxidation by acetic acid bacteria. Biosci. Biotechnol. Biochem. 1999, 63, 2102-2109. [CrossRef]

67. Yang, H.; Yu, Y.; Fu, C.; Chen, F. Bacterial acid resistance toward organic weak acid revealed by RNA-Seq transcriptomic analysis in Acetobacter pasteurianus. Front. Microbiol. 2019, 10. [CrossRef] [PubMed]

68. De Ley, J.; Swings, J. Genus Gluconobacter. In Bergey's Manual of Systematic Bacteriology; Williams and Wilkins: Philadelphia, PA, USA, 1984; pp. 275-278.

69. De Muynck, C.; De Melo Pereira, C.S.S.; Naessens, M.; Parmentier, S.; Soetaert, W.; Vandamme, E.J. The Genus Gluconobacter Oxydans: Comprehensive overview of biochemistry and biotechnological applications. Crit. Rev. Biotechnol. 2007, 27, 147-171. [CrossRef] [PubMed]

70. Wang, B.; Shao, Y.; Chen, T.; Chen, W.; Chen, F. Global insights into acetic acid resistance mechanisms and genetic stability of Acetobacter pasteurianus strains by comparative genomics. Sci. Rep. 2015, 5. [CrossRef] [PubMed]

71. Beppu, T. Genetic organization of Acetobacter for acetic acid fermentation. Antonie Van Leeuwenhoek 1994, 64, 121-135. [CrossRef]

72. Matsutani, M.; Nishikura, M.; Saichana, N.; Hatano, T.; Masud-Tippayasak, U.; Theergool, G.; Yakushi, T.; Matsushita, K. Adaptive mutation of Acetobacter pasteurianus SKU1108 enhances acetic acid fermentation ability at high temperature. J. Biotechnol. 2013, 165, 109-119. [CrossRef] [PubMed] 